kirja täydentää kirjallisuushistoriaa ja antaa virikkeitä sotienjälkeisen naislyyrikoitten uusia uria aukoneen tuotannon ja edelleen kiinnostavan modernismin lisätutkimukseen. Runsaudensarvi on avattu! Toivottavasti opiskelijat ja tutkijat tarttuvat sen antiin.

\title{
Kirjoittaja
}

Siru Kainulainen, dosentti, Kotimainen kirjallisuus, Turun yliopisto (sirkai[at]utu.fi)

\section{Spännande metaberättelse om seglivade myter inom Södergran-forskningen}

\author{
Agneta Rahikainen: Poeten och hennes apostlar. En biomytografisk analys av Edith \\ Södergranbilden. Helsingfors: Helsingfors universitet, 20 I4. 269 s.
}

Berättelsen om författares liv och verk inbjuder till särskilda typer av berättande där relationerna mellan liv och verk, eller för all del mellan verk och död, uppträder $\mathrm{i}$ ett begränsat antal varianter. Någon med en Vladimir Propps känsla för systematik kunde kanske räkna ut i vilka transformationer författarbiografin materialiseras.

En annan rysk formalist, Boris Tomasjevskij, har myntat begreppet biografisk legend, som fångar hur biografin byggs upp av en räcka anekdotiska "mikro-narrativ" eller biografem (det senare begreppet är myntat av Roland Barthes), där centrala händelser återkommer och traderas $\mathrm{i}$ likartade versioner. Den biografiska legenden innebär ofrånkomligen ett möte mellan fakta och tolkning. Författarbiografin som framställningsform, som genre, uppvisar också starkt fiktiva drag, där den tuberkulösa eller suicidala baklängesläsningen (bilden av döden/dödsorsaken styr tolkningen av livet) och den barndomstraumatiska bakifrånläsningen (bilden av barndomen styr tolkningen av livet) hör till de mönsterbildande.

Då dessa författarbiografiska berättelser rymmer en hel del litteraturpolitik bildar de en tacksam utgångspunkt för motröster och revisioner - och för nya berättelser, som på ett metaplan undersöker och avslöjar övrigas blottor och försanthållanden. Agneta Rahikainens avhandling Poeten och hennes apostlar. En biomytografisk analys av Edith Södergranbilden, är en sådan metaberättelse. Underrubriken pekar mot 
studiens metodiska huvudfokus, hämtat från biografiforskaren Michael Bentons studier kring hur myter uppkommer och muteras över tid. Ett annat centralt verktyg har hämtats från Petra Broomans Hayden White-inspirerade användning av "associativa ordfält" eller "strings", där frekvent återkommande ord eller fraser ställs samman för att avslöja underliggande stereotyper. Båda dessa redskap visar sig fruktbara i Agneta Rahikainens synnerligen systematiska och spännande studie över hur bilden av Södergran formuleras, förvaltas och förändras genom decennierna.

Rahikainen spårar livskraftiga felaktigheter tillbaka till själva urkällan och följer dem sedan genom den fortsatta litteraturhistoriska förmedlingsprocessen. Det hela startar i den samtida kritiken, reduceras ner ytterligare i minnesorden och de tidiga eftermälena, för att därefter med smärre variationer traderas i översiktsverk och nya studier kring författarskapet. Redan nekrologerna skrivna av Elmer Diktonius och Jarl Hemmer "uttalar det mesta av det som kommer att utgöra de mest livskraftiga myterna om Södergrans liv och diktning", skriver Rahikainen (s. 77). Och det är nu, tillägger hon, som den verkliga kampen om att rätt tolka och placera författarskapet startar, med Hagar Olsson och Diktonius som självutnämnda förvaltare. Här blir Södergran det missförstådda geniet, undantagsmänniskan och sierskan. Kanoniseringen och mytologiseringen är igång.

Den här metaberättelsen om skapandet av Edith Södergranbilden bär på en stark dramaturgi, med Gunnar Tideström i skurkrollen. Tideströms mönsterbildande biografi från 1949 likställer liv och verk, patologiserar, sexualiserar, exotiserar och styr in tolkningen mot det entydigt tragiska. Men även tidigare "apostlar" som Elmer Diktonius och Hagar Olsson sprider, visar det sig, en hel del desinformation som senare aktörer (bland dem just Tideström) plockar upp och reproducerar. I hjälterollen återfinns kvinnolitteraturforskningen under framför allt 1990-talet, med Ebba Witt-Brattström i spetsen.

Rahikainen navigerar med säker hand i materialet. Hon skriver medryckande och går in med nyktra och samtidigt kritiska kommentarer och tillrättalägganden. Hon inser att biografiskrivandet kräver ett visst mått av spekulation, samtidigt som hon insisterar på biografens förmåga att skilja på fakta och fiktion. Här finns spår av positivism, en tro på att om källäget bara var bättre, om inte centrala brev hade bränts - då skulle den sanna, avklarnade bilden träda fram. Jag tänker bland annat på den fylliga anteckningen ur kritikern Hans Ruins dagbok, som skildrar Edith Södergrans besök hos honom den I oktober 1917. Rahikainen upphöjer noteringen till "ett av de mest pålitliga vittnesmålen [...] eftersom det är nedtecknat följande dag", medan flertalet övriga dröjt flera decennier, "vilket förstås betyder att de inte är helt tillförlitliga". (s. 32).

Förutom att detta är en väl enkel distinktion är det rimligt att fundera över vem denna Edith Södergran var som så framfusigt navigerade i Helsingforsintelligentian - handlar det kanske snarare om "Edith Södergran", alltså om ett rolltagande? Rahikainen påpekar visserligen att 
författaren deltog i mytbildningen kring sig själv, men i själva analyserna syns inte mycket av ett sådant performativt perspektiv.

Det förblir också en smula oklart varför forskaren i studiens början vill införliva en egen "kortbiografi", och framför allt vilken roll denna är tänkt att spela i helheten. För det är inte en enbart deskriptiv text; tvärtom går Rahikainen in med tydliga markeringar och tillrättalägganden. Därmed skriver hon också ofrånkomligen in sig själv $\mathrm{i}$ den mytologiseringsprocess hon föresatt sig att granska. Centrala biografem eller "strings" återfinns och vidareutvecklas också; sanatoriemiljön, den komplicerade väninnerelationen till Hagar Olsson, Edith som den nya kvinnan som tar för sig och vet sitt värde. Rahikainen inser detta och placerar sig själv i Michael Bentons sista femte stadium i mytologiseringsprocessen, "den nutida biografens ambition att demytologisera genom att gå tillbaka till primärkällor och försöka skala bort alla mytologiska förhandsföreställningar”. (s. 20). Det är uppfriskande att Rahikainen med hjälp av Benton i samma stund slår hål på det potentiellt naiva i ett sådant anspråk - myterna blir vi aldrig helt kvitt, därför kräver också varje tid nya biografier.

Det är knappast svårt att idag se bristerna i de programmatiskt biografisk-psykologiska läsningarna. Samtidigt kräver ett historiskt studium blick för olika typer av statusförändringar. Att Södergran i det tidiga eftermälet utnämndes till ett barn eller en sierska står visserligen inte högt i kurs i dagens estetiska klimat, men gjorde det då. Den tragiska hjältinna vi nu betraktar som ett hjälplöst offer hade en annan potential för hundra år sedan. Här halkar den feministiska historieskrivningen lätt in $\mathrm{i}$ anakronismer.

Jag hade gärna sett en mer kritisk ingång $\mathrm{i}$ den kvinnolitterära revisionen av författarskapet. Även om denna "talking back" på många sätt innebar en välgörande nystart rymmer den också sina specifika typer av problem. Rahikainen är snabb med att hänga ut de forskare som inte tagit avstånd från Tideströms Södergranbild. Mot sin handledare Ebba Witt-Brattström är hon betydligt hovsammare och tillskriver denna "helt nya läsningar", dock utan att riktigt visa vari detta nya egentligen består.

Rahikainens avhandling inkluderar heller inte de mer samtida kontroverserna kring Södergrans författarskap. Jag tänker inte minst på den strid som rasade i svensk kulturoffentlighet 1997, kring Witt-Brattströms då nyutkomna bok Ediths jag. Edith Södergran och modernismens födelse i relation till Boel Hackmans licentiatavhandling "Diktens rum. Tradition och förnyelse i Edith Södergrans ungdomsdiktning" från året dessförinnan. Det är självfallet svårt för en doktorand att gå in i konflikter där handledaren är inblandad. Samtidigt hade det varit intressant att se hur kampen om och mytologiseringen kring författarskapet har fortsatt och ännu pågår.

Nu visar sig Agneta Rahikainens systematiska sätt att gå igenom receptionsmaterialet nog så avslöjande och hennes resultat bör rimligen frammana självkritisk reflektion hos varje litteraturhistoriker. Och efter de senaste decenniernas produktiva kartläggningar av hur enskilda 
kvinnliga författarskap behandlats i litteraturhistorieskrivningen börjar tiden kanske bli mogen för mer syntetiserande resonemang. Agneta Rahikainens ambitiösa avhandling om skapandet av Edith Södergranbilden bildar en mycket god grund till en sådan större berättelse.

\section{Författare}

Åsa Arping, universitetslektor, docent, Litteraturvetenskap, Göteborgs universitet (asa.arping[at]lir.gu.se)

\section{Maanaisen tanssi}

Toni Lahtinen: Maan höyryävässä sylissä. Luonto, ihminen ja yhteiskunta Timo K. Mukan tuotannossa. Helsinki: WSOY, 20 I3. 345 s.

Toni Lahtinen etsii tutkimuksessaan Maan höyryävässä sylissä. Luonto, ihminen ja yhteiskunta Timo K. Mukan tuotannossa tuoreita välineitä ymmärtää Mukan tuotannon avainteemoja. Mukan tuotanto on ollut viime vuosina vilkkaan uudelleenarvioinnin kohteena. Juha Ridanpään (2004), Leena Mäkelä-Marttisen (2008) ja Elina Armisen (2009) tutkimukset ovat nostaneet esiin Mukan tuotannon yhteiskuntakriittistä, romaanikerronnan keinoja koettelevaa ja pohjoista maisemaa aktiivisesti merkityksellistävää puolta. Maan höyryävässä sylissä jatkaa Mukan yhteiskuntakriittisten teemojen tarkastelua. Samalla Lahtinen kohdistaa huomion luonnon ja seksuaalisuuden teemoihin. Ne ovat paljolti määrittäneet kuvaa kirjailijan tuotannosta, mutta aiemmassa tutkimuksessa niitä ei ole tarkasteltu kovinkaan laajasti.

Tutkimuksessa Maan höyryävässä sylissä tarkastelun keskipisteessä on Mukan tuotannossa toistuva metafora maasta naisena. Lahtinen osoittaa, kuinka maanaisen kuvissa risteävät käsitykset ihmisen, luonnon ja yhteiskunnan suhteista. Tutkimus laajenee myös muihin Mukan teosten luontosuhdetta jäsentäviin trooppeihin, kuten ihmissuteen, erämaahan ja apokalypsiin Siinä sovelletaan ekokriittistä ja kirjallisuushistoriallista näkökulmaa. Lahtisen lukutapa pohjautuu Greg Garrardin teoksessaan Ecocriticism (2004) esittelemään näkemykseen laajoista luonnon ja kulttuurin suhdetta jäsentävistä troopeista. Samalla hän suhteuttaa 